RIDING AND DRIVING HORSES

+ THEIR BREEDING AND REARING B Y

MR. WALTER GILBEY 


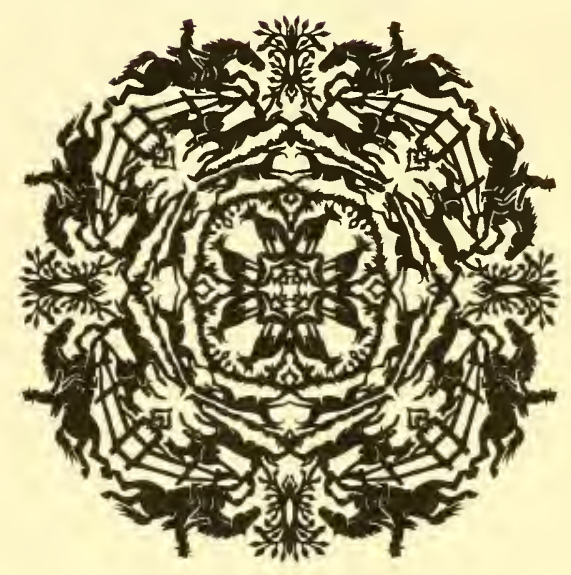

JOHN A.SEAVERNS 




\section{Riding And Driving}

\section{Horses}

THEIR BREEDING AND REARING

BY

Mr. WALTER GILBEY

March 1885 



\section{RIDING AND DRIVING HORSES}

\section{THEIR BREEDING AND REARING}

Address of Mr. Walter Gilbey at the Farmers' Club, London, 2nd March, 1885, and discussion by

\begin{tabular}{|c|c|c|c|c|c|c|}
\hline Lord CarRINGTON ... & $\cdots$ & $\cdots$ & $\cdots$ & $\ldots$ & $\ldots$ & 3 \\
\hline Mr. Edmund Tattersall & $\ldots$ & $\ldots$ & $\ldots$ & $\ldots$ & $\ldots$ & 33 \\
\hline The Duke of Westminste & R, K. i. & $\cdots$ & $\ldots$ & $\cdots$ & $35 \&$ & \& 39 \\
\hline Mr. Anthony HaMond & $\ldots$ & $\ldots$ & $\ldots$ & $\cdots$ & $\cdots$ & 37 \\
\hline Col. Kingscote, C.B. & $\ldots$ & $\ldots$ & $\cdots$ & $\ldots$ & $\ldots$ & 40 \\
\hline Mr. J. K. Fowler ... & $\cdots$ & $\cdots$ & $\cdots$ & $\cdots$ & $\cdots$ & 42 \\
\hline Mr. F. Sherborne ... & $\ldots$ & ... & $\ldots$ & $\ldots$ & ... & 44 \\
\hline Mr. JACOB WiLSON $\ldots$ & $\ldots$ & $\cdots$ & $\ldots$ & $\ldots$ & $\cdots$ & 44 \\
\hline Major DASHWOOD $\quad \ldots$ & $\ldots$ & .. & $\ldots$ & $\ldots$ & $\ldots$ & 46 \\
\hline Mr. T. B. WOODWARD & $\cdots$ & $\ldots$ & $\ldots$ & $\cdots$ & $\cdots$ & 47 \\
\hline Capt. Fife $\quad \ldots$ & $\ldots$ & $\ldots$ & $\ldots$ & $\cdots$ & $\cdots$ & 48 \\
\hline Mr. Walter Gilbey (reply) & )$\ldots$ & $\cdots$ & $\cdots$ & $\cdots$ & $\cdots$ & $5^{\circ}$ \\
\hline
\end{tabular}





\section{RIDING AND DRIVING HORSES}

\section{THEIR BREEDING AND REARING}

The Chair was taken by Mr. William Eve, the President of the Farmers' Club. There was a large attendance of Members and Visitors present.

Mr. Walter Gilbey, of Elsenham Hall, Elsenham, Essex, introduced the subject as follows:-

FOR many years the subjects dealt with in this Address have interested me deeply. Twelve months ago I made application to Mr. Druce, the Secretary of this Club, to be allowed to call attention to them, but was unfortunately too late, all arrangements for $\mathrm{I} 884$ having been then made.

Very many causes have been assigned for the decline of horse-breeding. It will be noticed that I accept one only, to wit, the failure in persevering to raise animals of size, quality, and value. The principal object which I have in view, therefore, is to make our shortcomings in this respect more generally known, and to offer suggestions for breeding superior horses, as these latter will always command a ready sale at prices remunerative to the breeder.

It is an admitted fact that the true-bred English hunter, hack, carriage and draught horse cannot be equalled in any other country. We may import from foreign lands corn, meat, dairy-produce, vegetables, 
eggs, and other luxuries of excellent quality, and to an unlimited extent, but horses of a high class must be raised at home.

At the present time there is a greater demand than ever for animals carrying from 12 to 15 stone, which will hunt or hack, and also prove suitable as match horses for carriage purposes. Horses of this type indeed, square-made, sizeable, with proper courage and action, can scarcely be obtained.

In proof of this it is only necessary for a good judge to visit the yards of our Metropolitan and country dealers, and he will soon discover how hard and costly a job it is to pick up a London brougham horse, or a match pair from 15.2 to 16 hands in height, with good feet and legs, stylish in carriage, and workably sound. During the past few years, for such purposes buyers have had to content themselves but too often with foreign horses at extravagant prices. Hundreds of pairs of these flashy, soft substitutes, are sold yearly in London to purchasers, unconscious of their origin, at from $£ 200$ to $£ 500$ the pair, an anomaly for which it is unjust to blame the dealers when English bred horses are not to be found in the country. As the demand is thus beyond the supply, these enterprising men have now their agents on the Continent always ready to purchase the most "English" looking animals they can find, and it is only when they have been put to work that the soft, foreign "spot," is detected.

To show to what an extent this foreign trade is being carried on, it is only necessary to refer to the annual returns of horses imported into this country. The following table of foreign imports speaks for itself :- In the ten years between 1863 and 1872 , foreign horses were imported into these islands to the extent of only 29,I3 I head; but in the corresponding ten years, between I 873 and I 882 , no less than 197,092 head were imported. How can this alarming increase 


\section{$(7)$}

be accounted for? Supposing these animals to be of the value of $£ 35$ each, we have a loss to this country of $£ 5,850,600$.

It was stated in the "Daily Telegraph" only as recently as the 24 th March last:-

"Seven years ago one of the greatest authorities upon the subject of horseflesh that ever entered a stable concluded a letter with the following inquiry:- 'What then has become of our boasted English horse? Those that I now see are for the most part tall, leggy animals, without bone or action, and not fitted to make a hunter, or a carriage horse, or a riding horse up to any weight.'"

Similar opinions to the above were expressed by Lord Rosebery's Select Committee of the House of Lords in 1873 . That Committee sat seventeen times, heard evidence from numerous witnesses, and finally reported that " The deficiency of native-born English horses is due. first, to the exportation of mares to foreign countries; secondly, to the increased profits on sheep and cattle, which, from being more rapidly realised, are doubly attractive to the farmers as compared with those obtained by the breeding of horses; and, thirdly, to the increased demand for horses consequent upon a multiplication of population and wealth." And yet, with all this, and as a proof that there has been no lack of money offered as prizes at the various shows in the United Kingdom for thoroughbred stallions, hunters, hacks, and carriage horses, I estimate that more than $£ 5$, 000 yearly has been given away in prizes to these classes during the past twenty-five years.

The subject of our present supply of horses is one also that has met with ample consideration at the hands of most competent authorities. In the I9th vol. of the "Royal Agricultural Society's Journal," Earl Cathcart remarks that, failing other writers, he was inspired to undertake, from an agricultural point of view, the difficult task of compiling some opinions on what he is pleased to call the "too long neglected 
subject of half-bred horses for field or road, their breeding and management."

His Lordship's able article occupies fifty-five pages, and, with a view of showing the importance he attaches to the subject, he remarks, "The horse is one of God's precious gifts to the nation, for our comfort and pleasure in peace, for our credit and advantage in commerce, and may be for our safeguard in war."

He supports his statements by the opinions of several practical breeders, and gives also the names, extending back over twenty years, of persons asking for information on various points connected with his subject.

In addition, he quotes from the reports of Stewards and Judges of the Royal Agricultural Society, complaining of the Hunters and Carriage Horses exhibited at the different Shows for a period of twenty years, from 1863 to 1883 . Thus we find that in 1868 , at Leicester, in a fox-hunting country, "Stallions were a moderate lot, the Hunters being especially disappointing." At Manchester, in 1869, " the Thoroughbred Horses were bad." At Oxford, in I 870, we were told that "Inferiority generally prevails." At Hull, in 1873 , "The Show was not grand for Yorkshire." At Taunton, in $x$ 875, Lord Cathcart says, "In Somersetshire the Thoroughbred Horse is almost as unknown as the Dodo."

The Report for the Show at Kilburn, in 1879 , written by the Hon. Francis Lawley, states that no less a sum than $£ \mathrm{I}, 060$ was offered in classes for Riding and Driving Horses, and adds that the Thoroughbreds, however, were far from good.

At Derby, in $1881, £ \mathrm{I}, 000$ also was offered in prizes, but the verdict was that "Thoroughbreds, never strong at the Royal Shows, were there a very bad lot, the stallions for getting hunters being few in number and inferior in quality."

The foregoing remarks seem clearly to indicate a 
general falling off in high-class horses, and the anxiety felt in many quarters to ascertain the causes.

In the case of half-bred horses it is to my mind easy to explain why these have been bred in less numbers of late years than formerly. There may perhaps be other causes besides those which I shall assign, but the most important one it seems to me is that we have failed to follow up the system adopted by our forefathers. We have, I fear, been taken off the true and direct line by reason of the often expressed belief "that our best mares have left the country." I think, however, I shall be able to prove that there is no foundation for such constantly repeated, and, as I believe, baseless assertions; but that we have still two "races" distinct in lineage which, if properly mated, will produce mares of the type and usefulness attained fifty or one hundred years ago.

To commence, I maintain that in most cases the lack of success is attributable to the dam. Every farmer who possesses a mare, whether well or ill-shaped, sound or lame, thinks her good enough to breed from. I should say on the contrary do not breed from the old mare because she is an old mare, but select from your stud a suitable two or three year old filly, and the produce from her will repay you for its keep.

On this point Mr. Lumley Hodgson remarks in No. 37 of the "Royal Agricultural Society's Journal ":-

"On many small holdings, now consolidated, small farmers worked useful mares and bred valuable foals."

"We have lost the old useful short-legged Punch, which could ride, drive, plough, cart, or breed a hunter."

"Concerning mares generally we breed from the refuse, the worn out and worthless; yet by putting even inferior mares to good sound horses the breed generally improves."

"A thoroughbred horse can get a valuable general purpose horse from an active cart mare-you must have one with quality, a good game head, silky mane, good sloping shoulders, good action ; but do bear this in mind, you must have game and mettle in the mare. A sluggish, coarse, heavy mare, will assuredly breed a slug. The old-fashioned and unhappily virtually extinct Cleveland could ride 


\section{( 10$)$}

hunt, plough, and to a short-legged thoroughbred horse breed the best of hunters."

It is well known that in the breeding of every species of animal the research after one quality, while it leads to greater perfection therein, is often accompanied by manifest deterioration in other attributes. Such has been the consequence of aiming at speed, while the other essentials, such as size, shape, action, and strength, have been wholly lost sight of. Horses can be reared according to the wishes and instincts of man, and the blood of the thoroughbred has been sought for and used as though pace was the first and only essential.

With reference to this subject, I may quote the following remark of Mr. Booth, in support of Earl Cathcart's article :-

"In addition and supplementary to blood we must have substance from somewhere. Weight-carrying half-bred horses, chargers and hunters, and strong and nimble and enduring hacks, are and will continue to be for ages to come, more and more in demand, and will and must be continually, perhaps increasingly produced in their natural home-England-and that in the greatest possible perfection. And if in this affair we cannot attain to the absolute certainty of science, the convergence of many minds and many experiences towards one centre may result in the evolution of some recognised principles See for example how Mr. James. Howard, M.P., practically treats the physiology of breeding, in his "Application of Natural I aws to the Breeding of Horses, Cattle and Sheep.' Mr. Howard was there enabled to come to the conclusion that certain cardinal points in the art of breeding have been fairly established. Such for instance as outward conformation being derived from the male parent, the internal organs chiefly from the female, and so on."

While on this question of speed and breeding, I may draw attention to another point. We often find that a mare has been mated with a thorough-bred horse because she is fast, in order to produce something still faster. She has proved to be good as a hunter, as a hack, or for driving purposes, and has already several strains of blood in her veins. Nothing, however, is known of her pedigree on the dam's side, she is smaller 


\section{( I I $)$}

than the stallion to be used upon her, and her dam was perhaps no bigger than she is herself

According to all established principles the produce from mares answering this description must degenerate in size, as the bulk of the foal must accord with the room through which the foal has to pass. When the male is much larger than the female, the offspring is generally of an imperfect form. If the female be proportionately larger than the male, the offspring is of an improved form. The improvement depends on this principle, that the power of the female to supply her offspring with nourishment is in proportion to her size, and to the power of nourishing herself from the excellence of her constitution. The size of the fotus is generally in proportion to that of the male parent, and therefore, when the female parent is disproportionately small, the quantity of nourishment is deficient and her offspring has all the disproportions of a starveling. The larger female has also a larger quantity of milk, and her offspring is more abundantly supplied with nourishment after birth. Abundant nourishment is necessary to produce the most perfect formed animal, from the earliest period of its existence until its growth is complete. The power to prepare the greatest quantity of nourishment from a given quantity of food depends principally on the magnitude of the lungs, to which the organs of digestion are subservient. To obtain animals with large lungs, crossing is the most expeditious method: because well-formed females may be selected from a variety of large size to be put to a well-formed male of a variety that is smaller. By such a mode of crossing the lungs and heart become proportionately larger, in consequence of a peculiarity in the circulation of the foetus, which causes a larger proportion of blood, under such circumstances, to be distributed to the lungs than to other parts of the body; and as the shape and size of the chest depend upon that of the lungs, hence arises a large chest, 
which is produced by crossing with females that are larger than the males.

As an illustration of this we have the larger foal obtained from the roomy cart-mare crossed with a thoroughbred stallion, in comparison with the opposite cross of a thoroughbred mare with a cart stallion.

The foregoing opinions of Henry Cline are deduced from experience gained upon his farm at Southgate, in the last century, and are supported by all the most eminent practical breeders, such as Bakewell. Cully, Somerville, Parry, and others: as well as by most theorists, among whom we may mention Dr. Coventry, - who wrote a pamphlet in I 806, entitled "Remarks on Live Stock,"- -and also Darwin, Hunt and Young.

That the size and value of horses bred in Ireland have decreased is easily discernible by those who remember their former excellence, as contrasted with the exhibits during the last few years at the Dublin Shows. For one sizeable animal up to weight or fit for coach or carriage purposes, there are at present twenty-five small undersized horses, most of them not weighty enough to pull a London Hansom cab. In reality, in trying to meet the demand for hunters and steeple-chase horses, the craze for blood to go the pace has been increasingly in the ascendant, and size and substance have been consequently lost.

Ireland being a country which still holds its name as a large producer of horses, it is certain that very many of the best hunters in England still come from there. Nevertheless, the percentage of square-made, sizeable, riding and driving horses is getting smaller and smaller every year.

As a rule, it must be admitted that Englishmen have not made a study, or given much thought to breeding horses, with the exception of racers and of massive beasts of burden for draught. The intermediate animals, other than the race-horse or the draught-horse, have been bred by accident 
or caprice, and are of mixed lineage. This brings me to the theory which, above all others, I am anxious to impress upon your minds. To my thinking there are only two distinct and definable types of the equine race, the Thoroughbred and the Draught. On these two types long continued, costly and thoughtful care has been bestowed with a view to found or constitute in them a distinctive lineage. From each of them classes have been established, which, by common practice, are called "breeds." Thus, as an outcome of the first- "the Thoroughbred"- we have the race-horse pure, the Hackney, the Hunter, and other varieties of light animals. As an outcome of the second, or draught-race, we have the breed of Agricultural and other heavy horses, known as Shire, Suffolk, Cleveland, and Clydesdales.

This opinion I find supported in a work, "Cully on Live Stock," published so long ago as I794, in which the author says :-

"It is generally thought that we have only two original breeds of horses in this Island, viz., the race of blood kind and the black cart breed, the rest have been supposed to be only variations from these two by repeated crossings."

\section{The Thoroughbred.}

The history of the blood horse should be well known, since it has been told by hundreds of able and experienced writers during the past century.

Let me turn first to the "Sporting Magazine," Vol. I. Nov. I 792, in which I find the following remarks :-

"In taking a review of Horses in England from early times to the present, they seem only to have been divided into two general classes which may be ranged under two distinct periods of time; in the FIRST era, it was an universal custom for horsemen to fight in armour, and the service was so severe, that only large stout horses were equal to the task. It was therefore the constant endeavour of the English to raise such a breed as should be able to answer the purposes required of them."

"When armour was rendered useless by the invention of fire-arms, the great horse ceased to be necessary. Lighter and nнore active 
animals were introduced and here begins the era which comprehends the SECOND class of light and soft denomination. To encourage and promote a race of these horses public rewards were given, wagers allowed to be risked and races instituted; which from the curiosity they excite and the pleasure they afford always draw an incredible number of spectators; so as almost to supply the place of an Olympic triumph to the owner of the victorious steed, and, from these concurrent causes, prove a most powerful incitement to self interest; too powerful for the advancement of that plan which they were originally intended to promote; for, as if more speed were the only requisite in a horse, all the properties and qualities have been sacrificed to it; but losing on one hand what they gain on the other, and being weakened and refined, they become less serviceable from the excess of the very quality which is reckoned their chief recommendation."

It is not necessary that I should contrast the thoroughbred of to-day, for racing purposes, with his predecessors of the last century. We know what they are now in comparison to what they once were, by the old records of the long-distance courses and four mile heats, in which horses carrying twelve stone competed, and in which bottom and stoutness were equally important, and by reference to past numbers of the "Racing Calendar," in which particulars of their performances are fully recorded. Happily, also, we possess innumerable old pictures of race-horses by celebrated animal painters, such as Wootton, Seymour, Sartorius, George Stubbs, Chalons, Ben Marshall, Gilpin, and others.

Among these George Stubbs, R.A., was the pioneer of horse painting, and his six years spent in Lincolnshire on the wolds, in depicting the horse, will immortalize his name. He occupied there an old barn-like sort of a home where he carried on his studies in anatomy, the results of which he published in eighteen plates, and these original drawings are now to be seen at the Royal Academy's rooms in Old Burlington Street, to which Society they were bequeathed by the late Thomas Landseer, brother of Sir Edwin Landseer, the eminent animal painter. Previous to George Stubbs, all other animal painters had merely delineated 


\section{(15)}

the horse without possessing any genuine knowledge of its anatomy, hence the stilty and rocking-horse appearance of these animals, which could have never been real or life-like. As I have thought perhaps it would interest you, I have brought here with me four pictures of Marske, Eclipse, Shark, and Mambrino, by George Stubbs, R.A., that you may realise the character of the race-horse of a century ago.

Art, indeed, may claim to have done much for the horse, and there was something, therefore, in the suggestion of Earl Cathcart that :-

"The Royal Academy might perhaps with advantage devote one of its empty rooms to a Winter Loan Exhibition of the portraits of famous horses by excellent artists, of which pictures, say from I 700 to 1820 , the country is replete. How popular, how instructive and encouraging such an exhibition would be ; and how its arrangement would have delighted the late President of the Royal Academy, Sir Francis Grant, who took pleasure not only in the weapon of his art, b.t also in the more exciting brush of reynard, the fox ? What a trotting out there might be of clever old horses by such clever old artists as Alken, Chalon, George Morland, Stubbs, Sartorius, Fernely, Herring, Ward, Landseer, and no doubt many others who, if unrecalled by me, are yet well known to fame."

Feeling the directors of the Royal Academy would not think it of sufficient public interest, I have arranged with my friends, Messrs. Vokins, for an exhibition of paintings, engravings, \&c., connected with the works of G. stubbs. Of these, as well as books of reference, \&c., I have a large quantity, which I have placed at their disposal. Amongst other curiosities in that way, I may mention a copy of a letter from Sir Joshua Reynolds to Stubbs, complaining that while he received only $£ 50$ for his portraits of his sitters, he (Stubbs) obtained as much as $£$ I 00 for his paintings of a horse. Leaving art, however, let us return to our subject.

In selecting thoroughbred stallions it must be remembered they have not at the present time the old attributes of strength and stamina. While more refined and elegant they are not so suitable for crossing with 
light weedy mares, and hence the disappointment which has caused so many to abandon the rearing of half-bred horses.

Mr. George Lascelles, in attempting to show, how by keeping the right sort of mare and using the most suitable stallion, a farmer may reasonably expect to breed a sound, saleable horse, with substance and action, remarks :-

"I have had some experience and the opportunity of watching the result of breeding from good well-bred hunting-mares with at least three crosses of pure blood, and I must admit that the number of valuable horses, say up to fourteen stone, bred in this way is very limited, over a considerable number of years. I attribute this failure to the attempt to get size from the sires used. A big thoroughbred horse and a well-bred half-bred mare may produce a tall leggy horse, but seldom a short-legged strong one. Some of our best weight carriers have doubtless been first-cross from the thoroughbred horse and a cart mare, and I consider that it is indispensable that the mare should have the size and substance, and from these sorts of mares it has been found that medium sized and even small short legged thoroughbred horses with good sound feet, good legs and action have proved the most successful sires. We all in Yorkshire look back to horses got by Old President, Mac Orville and Perion, all small horses, but they were mated with what were called Chapman and Cleveland mares, which did the farm work in our northern dales, and produced the best hunters and carriage horses of the times. These mares were got by half-bred sires out of the cart-mares of the country, the sires generally having a cross of thoroughbred blood. They were kept as much as possible to a good bay colour, with black legs, and the colts were always saleable either for hunting or harness. The fillies were kept on the farms and bred from again. This I am inclined to think is the only way that horse breeding can pay the farmer."

The task the breeder sets himself in seeking to procure suitable sires is not an easy one, as it is essential in selecting a thoroughbred stallion for stud purposes to avoid tall, leggy, oversized animals, and particularly those having hereditary diseases, crooked fore-legs, curby or sickle hocks, and ewe-necks. Above all other considerations, the sire should possess good body and feet, straight and true action. Pliability of the knee is not necessary, but good hocks and galloping action cannot be dispensed with. It is, on the other 
hand, of no consequence that he should have won races, except on long distance courses carrying weight, and still less material is it that he should have been successful in procreating stock to run in the first rank as two and three years old.

The qualities required in a successful breeder are well summed up by $\mathrm{Mr}$. Maynard in his contribution to Earl Cathcart's article:-

"Not one man in a thousand has accuracy of eye and judgment sufficient to become an eminent breeder ; if gifted with these qualities, and he studies his subject for years, and with indomitable perseverance devotes a life time to it, he will succeed and may make great improvements : if deficientin these qualities assuredly he will fail."

"My father," he says, " bought a three-year-old colt by President trom a really good Cleveland mare, which turned out well; he rode the horse himself, with his own hounds, and with Mr. Millbanks for two years, and then sold him to the late Sir Harry Goodricke for 400 guineas. He sold another to the Duke of Cleveland for 400 guineas, by Woldsman, out of a plough mare : this horse could not be beaten with fifteen stone on his back across any country with hounds. Another beautiful weight carrying hunter my father sold to the late Sheldon Cradock for 400 guineas; he was by Petronius, out of a Cleveland mare. I may mention that the Cleveland mares in these days were good steppers and full of pluck. I saw a farmer one day when we were hunting with the late Kalph Lambton, take his mare from the plough, jump on her back, with winkers bridle and collar round her neck, and go for about five miles across country, take every fence before him, and was there when we killed our fox: this very mare afterwards bred some famous hunters crossed with old Mac Orville."

"I have had myself," he goes on to say, "many first rate hunters by old President, by Mac Orville and Perion; one horse by President, bred by Mr. Rigg, of Yafforth, out of a plough mare."

"Another fine mare by Mac Orville, dam a Cleveland mare, I bought from Mr. J. Parrington, no day was too long for her, and no country too stiff. I sold her to the Hon. H. Willoughby, afterwards Lord Middleton; his huntsman, Morgan, told me she was the very best hunter he ever crossed. I also sold a horse by Perion, similarly bred, to Mr. Willoughby, which proved a grand hunter. John Payne, of Market Harborough, bought many hunters from me by President and Perion, out of Cleveland mares, and they always gave great satisfaction."

Before leaving this question of the thoroughbred, I would remark that, it is to be hoped the valuable 
prizes offered by the Committee for Thoroughbred Stallions, at the show which opens to-morrow at the Royal Agricultural Hall, Islington, will introduce to breeders animals well adapted for getting useful halfbred horses. Such a system claims for itself all the advantages which Lord Calthorpe advocated in a letter to the "Times" in I875, in which he recommended the provision of stud horses by private subscription rather than by Government aid. The owners of stallions winning any of the prizes are required to guarantee twenty subscriptions for serving tenant farmers' mares at a fee not exceeding $£ 2$ ros.

So far as the size of thorougbred horses is concerned we have some curious statistics.

Admiral Rous stated fifteen years ago in "Baily's Magazine," that the stature of race-horses had increased an inch in every twenty-five years since I 700, and that whereas the average size of horses then was I 3 hands 2 in., the average in 1870 was 15 hands 2 in.

If we cross the Atlantic we shall find that all the fastest trotters in the United States descend from the native breed crossed with English Thoroughbreds, which were then only small horses. "Imported Messenger," the son of "Mambrino," bred by Lord Grosvenor, was exported to America towards the close of last century, and most of the celebrated trotters in that country trace back to him.

The Duke of Westminster has in his possession the original purtrait by George Stubbs, R.A., of this thoroughbred stallion "Mambrino," the sire of "Imported Messenger," who won many long distance races on the English turf. This oil painting may be taken as a faithful likeness; but no one can examine it without perceiving how little resemblance it bears to many of the flimsy racehorses of the present day. The editor of Hiram Woodruff's well-known and entertaining book, "The Trotting Horse of America," states that one hundred million dollars, or twenty 
million pounds sterling, struck American soil "when 'Imported Messenger" came charging down the gang-plank of the ship which brought him to the United States."

As an evidence of the value of the blood imported into the United States from England, we may notice that in the number of the "New York Spirit of the Times," which appeared upon the $24^{\text {th }}$ of last January, the names are given of no less than 994 trotters liable to appear in public during the present year, all of which have, in American phraseology, "records of two minutes thirty seconds or better." When we remember that there is not at this moment a single English horse capable of trotting a mile in three minutes, we shall easily see what the value of these 994 wonderful performers must be to our Transatlantic kinsmen. Nor should it be forgotten that the American trotter is as much the result of careful selection, of mixed breeding, and of education, as the finest Anglo-Arab Thoroughbred that ever won races in this country.

Turning from the United States to our Australian Colonies, the following remarks on Australian Horse Breeding, may not be without interest :-

"Colonel Williams the Director of Remount Operations in India, has expressed his opinion of Australian horse breeding in the form of a report. He has inspected the principal studs of Australia and New Zealand, and regrets that he was unable to visit Queensland. The object that the Government of India had before them in delegating Colonel Williams to visit Australia was that he might acquaint himself with the source of supply, present and future, of remount horses for India, and also inipart information to those interested in the trade, either companies or shippers, of the exact requirements of the Government in regard to the supply of horses. $\mathrm{He}$ states as follows :- " From observations made throughout your colonies, I am forced to come to the conclusion that, with few exceptions, the breeding of horses is confined to two classes-the thoroughbred and the heavy cart-horse. The medium kind of horse is sadly wanting. This class should supply you with carriage and buggy pairs, spring cart and cab horses, and heavy weight hacks, and obviate the necessity of the ever-recurring remarks in the state of the horse market reviews of "No carriage pairs to hand; buggy pairs 
and saddle horses scarce ; many inquiries for them,' \&c. And I take it the reason is because of late years sufficient attention has not been paid to the breeding of this class of horse alone. but that it was sufflcient if the culls from the thoroughbred or the light ones from the heavy stock were sold to meet that demand."

"In years gone by it was not uncommon to hear of mares having arrived from England for breeding purposes. Now-a-days it is a rarity to hear of any coming. The consequence is that you have gone on breeding from those you have; you have not carefully and thoughtfully culled out your light fillies, but you have bred from all; the natural result has followed, a great preponderance of your stock has become light, and you are hampered with it now. 'I'o remedy this state of things, and for you to breed horses that will repay you, it behoves you to change your system of breeding, for it is evident that you cannot all at once change your light mares."

Much of the advise here given to Australian breeders would not be thrown away in this country. It is time, however, that we turn from the consideration of the thoroughbred to the draught horse.

\section{The Draught Race.}

Here, again, it is not difficult to trace the history of this type of animal. Going back 300 years we shall find that the native horse in this country was undoubtedly undersized. An Act of Parliament was passed as long ago as 32 Henry VIII. enacting that no stallion, not being I 5 hands, should be turned out on common or waste lands.

During this and the next century premiums were held out to increase the size. Large horses were imported from the low lands of Holland and Friesland to cross with the English breed for the purposes of war, and thus to supply chargers fit to carry the Cavaliers in heavy armour (vide Albert Dürer's print about 1500 ). The knight, with all his accoutrements, rode between 25 and 30 stone. The late Colonel Burnaby, of the Life Guards-whose loss we deplore-when mounted upon his black charger, weighed only 22 stone.

This large breed spread throughout England, and especially through the districts between the Humber 


\section{$(2 \mathrm{I})$}

and the Cam, occupying the rich Fen lands of Lincolnshire and Cambridgeshire, and extending westward through the counties of Huntingdon, Bedford. Northampton, Leicester, Nottingham, Derby, Warwick, and Stafford to the Severn; but while extensively bred upon these rich and succulent pastures, the breed was not confined to the counties just named. It was to be found both northward and southward, and retained its typical character, varying but slightly with the soil, climate, and food. After the period when armour went out of use, by reason of the introduction of improved firearms, the breed was still maintained, as the increased wealth of the country created a demand for massive animals adapted to other purposes.

It must not be forgotten however that down to the end of the 17 th century agricultural operations were in the main carried on by oxen.

The mares were crossed with the racehorse of that day and threw superior foals, suitable when grown up, for carrying heavy weights in the saddle, and for tugging coaches, carriages, and similar conveyances along primeval roads.

As late as I795, when Arthur Young wrote his various works describing his tours through the counties of England and Scotland he found on many farms that horses were but seldom used. Oxen were the beasts of burden for the heavy work upon the land. This famous writer has no good word to say in favour of employing horses for ploughing, but on the other hand he strongly recommends the continued use of oxen as the cheapest and best animals for the purpose. There can be little doubt that the draught-horse of that period was "the general purpose horse," as it is undeniable that he performed all the duties required of him, ploughing in some cases, working in carts, and going to market ridden or driven by the farmer, and sometimes accompanied by his wife or daughter.

In those counties where horses were employed 


\section{$(22)$}

upon the farm they were small in size, in comparison to the animals used on the land at the present time, and Marshall's Rural Economy of Norfolk," 2 vols., published in I787, says, "The farm horses of Norfolk were formerly a small brown-muzzled breed, light boned, but they stood hard work, and hard keep in a remarkable manner, and two of them were found quite equal to the Norfolk plough in the Norfolk soil."

Speaking of Yorkshire cart horses Mr. Cully says:-

"Yorkshire draught-horses, and particularly the Cleveland Bays, are so justly esteemed for their great exertions in the coal and lime season. The weights carried, distance travelled, and the time it is performed in for several weeks together, are certain proofs of their activity, strength, and hardiness. Their colour is mostly bay, and their form is such that the mares, put to a full-blood stallion, breed excellent hunters and saddle horses, and to a half-blood horse, capital coachers or carriage horses."

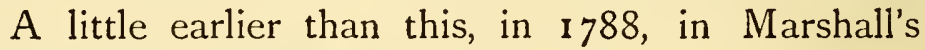
"Yorkshire," I find :-

"The Vale, the Wolds, the Holderness, probably employ a hundred Stallions. One hundred Mares are considered the full complement for one horse, some of them perhaps do not get fifty. On this calculation there are from five to ten thousand horses bred between the Eastern Wolds and the Humber."

"During the last twenty years some capital Hunters have been bred in Yorkshire. This change was principally effected by one horse, Jalap, a full-bred horse, whose pedigree and performances are well known upon the turf. He is still living, and what is remarkable, last season, at the age of thirty, covered several Mares. His leap, five guineas each for blood Mares, two guineas for * "Chapman's Mares."

"Almost everything depends upon the Mare."

"What are a few guineas in the first purchase of a good Mare? And what are a few days ploughing, or a few rides to market, compared with the difference between a race of good and of ordinary horses."

In Nimrod's letter to the "Sporting Magazine" for September, 1827 , says :-

"Mr. Mason also breeds some valuable horses, and amongst

* A dealer or market man. There are some old pictures and prints in existence with the Farmer and his Wife on one horse riding to Market 
others he showed us a very fine three-year-old colt of the true Cleveland bay breed, which he intended using as a stud horse He was upwards of $\mathrm{r} 6$ hands, with remarkably good legs; and, barring his head, which was coarse, was very handsome. I believe this breed was much sought after by the heroes of old. Doubtless from their hardihood and activity there is no species so calculated for agricultural purposes as Cleveland bays; and good hunters to any weight are bred from the second cross with the English racehorse and a Cleveland mare."

It will be observed that extraordinary high knee and all round action is the general characteristic of the draught race, particularly in the Shire and Clydesdale breeds. I do not mean the massive stallions of these breeds fit only to be stud horses for begetting animals like to themselves. I allude to many Shire and Clydesdale stallions, such as have been before the public. At the Glasgow shows of Clydesdale stallions I have seen many horses with the true action of the Norfolk trotter. I have in my mind's eye also, several "Shire" stallions, such as "Norfolk Wonder," exhibited at the London Show, I880; "Cromwell," in I882 ; "Champion" (Statters), a winner at many shows; and a stallion which I once possessed, named "Paragon." I will also mention two stallions which were sold at my sale last month, "Gay Spark " and "Crowland Chief." These, and very many draught stallions possessing good shoulders, have all the true high fore, and good hind action, which is depicted in a picture in my possession, of a "Trotting Cart Horse," painted by Sartorius, in I 818. I could also mention very many mares of the draught race with these good qualities; I will, however, name one only, which many of you have seen at the principal shows, Mr. Brierly's "Sensation."

The species of draught horse now in general use is well represented by four different societies :First, we have the Shire Horse Society, which, besides its Stud Book, recording the history of the breed, dating back to the last century, holds an Annual Show in London. 


\section{$(24)$}

Secondly, we have the Suffolk Horse Society. and its Stud Book. This Society is well supported by the County Agricultural Society, the Royal Agricultural Society, and the Essex Agricultural Society, which offer special prizes for the "Suffolk" breed.

Thirlly, The Cleveland Horse Society. This recently established association has issued its first volume. There are one or two Yorkshire Agricultural Shows, which have favoured the reputation of this equine produce, and it is to be hoped that special classes for "Clevelands" will be offered at the principal shows in England.

Fourthly, we have the Clydesdale Horse Society, which, besides its Stud Book, offers annually, premiums and medals at Glasgow and various Agricultural Shows, while the Royal Agricultural Society of England have for some years had separate classes for this breed.

The mention above made of various Horse Societies naturally leads me to the question of stud books.

A great deal has been written as to the advisability of establishing a Society for Registering Hunters in Stud Books. Advocates recommending such a step must have persuaded themselves that there were sufficient half-bred mares in the country to be worth recording; but, in truth, up to the present time the experiment would have ended in failure, as such animals must first be bred, and hunters can only be bred in future as they have been in the past. by judicious cross breeding between the Thoroughbred and Draught, and by selection of sire and dam to correct faults.

In "Post and Paddock," on the breeding of hunters, it is stated by the "Druid," writing in 1856 :-

"He could never get the exact cut of a hunter he had set his mind on, till in despair, he put his short-legged cart mare to a thoroughbred horse. Her first filly was laid up in lavender till she was rising five, and then crossed with a thoroughbred, and this union inaugurated a long line of fast, weight-carrying hunters, which have been the apple of his eye for years. Others, while they think that to carry weight, nothing can beat the cross 
of a blood horse with an active high-shouldered cart mare, as firmly maintain that the second remove is never so good as the first. And on we go through a perfect tide-roll of breeding specifics, alike pleasurable and speculative. The best instance of the first cross that we remember, was a mare called "Poll of the Vale," by "Great Britain," who was bought at four years old out of a team for $£ 28$, with hair enough on her legs to stuff a moderate sized pillow. After carrying a 17 stone for two or three seasons, she was sold for 300 guineas to the Hon. Wellesley Pole, with a promise that she should be given back when she could hunt no longer; and although she passed through several hands this contingency was kept alive, and she died in giving birth to a colt, by Vandyke junior, in her old owner's paddock. A Sir Joshua mare, called Cashmere, was similarly bred, and after being bought at Melton Fair for $£ 38$, passing through Mr. Maxse's hands, and making $35^{\circ}$ guineas at Tattersall's, she became the property of the late Mr. John Moore, of the old Melton Club, for 300 guineas, and was in his stud when he died."

"Our own impression is, that to secure a good hunter the size should be on the side of the dam, and the breeding on that of the sire. A large roomy mare should be put to a small, compact, blood horse. Sir Harry Goodricke, whose courtesy and discrimination of character, both in man and horse, has never been surpassed, was especially particular on this point, and would never buy a hunter whose sire was not thoroughbred."

A letter signed "Yorkshire," it is true, ridicules the idea of forming a "Hunter's Stud Book." The writer says, "The idea seems to me a most extraordinary one. What is it proposed to enter therein? A mare that has bred a hunter, that ought to breed one, or that has been one herself? Or will it be only those with a certain number of crosses of blood, after the system of the Herd Book? I know an excellent hunter out of a dun pony, and another equally good out of a mare doing daily cart work. Would either of these have been guaranteed by the stamp of the Stud Book? And yet each have been sold for $£ 200 . "$

In the face of these disparaging remarks, perhaps however, some ultimate good would result if an intermediate breed of mares between the thoroughbred and the draught could be founded, and a register kept of such cross bred animals. This could be done 


\section{$(26)$}

by forming a Society to publish a register enrolling all the hunter mares which may win prizes at future shows in the United Kingdom.

Of this, at least. I am convinced, that it is impossible to over-estimate the good effect which the different Stud Book Societies are producing, or the importance of maintaining them.

I do not believe, however, in relying alone upon Stud and Herd Books, and unless public form be sought out, through the agency of animals with a stamp of merit upon them, coming into competition with each other to be judged accordingly, such Societies will tend, in my opinion, to but little good.

Undoubtedly, in proportion as the different breeds approach more nearly to perfection, so much larger will be the choice of animals suited by judicious crossing for obtaining the objects which we all have in view.

Low, in his work on "Domesticated A nimals," published in 1845 , says, speaking of hunters :-

"These form a class rather than a breed of horses, because different varieties of horses may be used for the purpose of hunting, as the race-horse itself, or the superior class of saddle horses of any kind."

"The modern hunter differs greatly in his character and form from the horses formerly employed in chase in this country, having partaken of that tendency to a lighter form of which all the horses used for the saddle have partaken and this in an increasing degree within the last half century.

The race-horse is designed essentially for the exercise of the property of speed, the hunter is also required to posiess a degree of speed sufficient for the uses to which he is destined, but with this he should be possessed of endurance and of the strength required for carrying the weight of his rider over an unequal surface."

"The tendency to the ewe neck, which in the short and violent gallop of the race course is admissible, would in the case of the hunter, be inconsistent with sensitiveness to the rein and the ease of the rider. The neck of the hunter should be sufficiently muscular, and his chest just so broad as to indicate strength without heaviness; the long stride of the racer not being required in the hunter, the latter should possess the conformation which indicates strength in the dorsal and lumbar regions, that is, he should be well ribbed home and have the back moderately short." 
"Although the change so widely produced in the horses of this country, by aiming at a higher standard, has doubtless given us animals more spirited, active, and graceful, it has, at the same time, had the effect of causing great numbers to be reared defective in form, deficient in strength and bone, and which have lost the hardy quality of the older races, without having arrived at the properties which superior breeding should communicate. The deterioration is generally admitted, and the causes are deserving of consideration as indicating the remedies."

\section{Mating.}

We come now to the most important part of my subject, viz. : that of Mating. By judiciously crossing or blending the two races-the Thoroughbred stallion, with all the quality he possesses, and the Draught mare, with size, frame, and constitution, well formed flat legs and high courage-animals may be produced which no other country in the world can yield. From the half-bred mares thus begotten cross breeding can again be resorted to, and so regulated by the selection of the thoroughbred or Hackney, as to re-produce improved size, strength, and constitution in the stock of riding and driving horses, available for general use. The great object of breeding on this principle is the production of animals of improved form which will repay the breeder; and experience has exemplified that this has only been attained in an eminent degree in those cases where the females were larger than the males.

"Were I," says Sir J. S. Sebright, writing in the past century, "to define what is called the art of breeding, I should say that it consisted in the selection of males and females intended to breed together, in reference to each other's merits and defects.

It is not always by putting the best male to the best female, that the best produce will be obtained, for should they both have a tendency to the same defect, although in ever so slight a degree, it will in general preponderate so much in the produce as to render it of 


\section{$(28)$}

little value. We must, therefore, observe the smallest tendency to imperfection in our stock, the moment it appears, so as to be able to counteract it before it becomes a defect."

Mr. Sawrey Cookson's remarks in No. 37 of the Royal Agricultural Society's Journal are worth attention here :-

"Many breeders," he says, "of thoroughbred stock, irrespective of shape either in sire or dam, send their best mares to the most fashionable horses, trusting entirely to high-class blood on both sides to produce a racehorse."

"The breeder, further to ensure size as likely to command a price, selects the big horse of the neighbourhood, advertised, as I have often observed, 'Standing nearly 16 hands 2 inches, with substance,' not knowing, or overlooking, the fact that the more size the more liability to all natural blemish."

The thoroughbred and the draught races are both peculiarly special to this country, having been built up by ourselves and our ancestors extending back hundreds of years, at a cost which the people of no other nation could realize. "Every Englishman loving a horse," has not scrupled to spend money on its improvement; money, which if brought together, would amount to a sum of not thousands, but millions. At the first blush this estimate will appear to be large, but when we remember the many ways in which money has been expended in this direction-notably in breeding for the turf alone-it will be seen that after all there is not so much exaggeration in this remark as might at first sight appear.

In the I6th and i 7 th centuries commissioners were specially sent to all parts of the world to select the best horses of each country for importation into England, and the importance of this subject at those particular epochs is frequently referred to by numerous contemporary authors.

At the present time it may be accepted that the agricultural or draught race is a composite production descended from stock which was common in the 
United Kingdom centuries ago, improved and built up from the old war horse, which possessed size, strength, and constitution. With no race are we better acquainted than with this latter, better known now as the old English or SHIRE horse as he has come down to us, improved by such famous breeders as Bakewell, Cully, and others, and the knowledge we possess of his lineage and pedigree extends back to the last century. He is also referred to by many writers before Arthur Young's time, and is presented to our view by the many pictures and engravings at the offices of the Shire Horse Society, some of them dating as far back as 1760 and i 780 .

The breed now varies in size, according to the climate and soil in our different counties; the heavy horses bred on the low rich fen lands will lose their size and hair when bred on up-land (chalk, gravel, or what is called mixed soil), but they will retain that grand quality of flat bone which is found only in the breeds known to have possessed fine silky hair.

It is well to remark, that where there is a profusion of silky hair there will certainly be found the correct quality of bone and well-shaped fore-legs. Round boned, calf-kneed animals are rarely seen in the Shire and Clydesdale breeds, and seldom or ever when the animal has plenty of fine silky hair.

I come now to the conclusion of my subject, and in doing so feel perhaps that I ought to apologise for its length, although I have endeavoured, so far as my own remarks have been concerned, to be as brief as possible. I hope, however, I have said enough to encourage my friends here to exert themselves in the cause which I have so much at heart, and which I believe to be one of great importance to the future welfare not only of agriculturists but the country generally.

Before sitting down, and with a view to simplify discussion, which,--looking at the thorough knowledge some of our friends present have upon the subject,- 


\section{$(30)$}

cannot fail to be of great interest and value, I will briefly summarize the various points which I have endeavoured in my Paper to bring out :-

Ist. The decline of horse-breeding as evidenced by the number of foreign horses imported of late years into this country.

2nd. The percentage of sizeable riding and driving horses is getting smaller every year, and the prices paid for them are greater.

3 rd. That lack of success in breeding is in most cases attributable to :-

a Want of care in the selection of young mares of sufficient size.

$b$ Sacrificing too much to speed, so that in the craze for pace, size and substance have been disregarded.

4th. To remedy this state of things, and in order to breed horses that will repay their owners, there must be a change in the system of breeding, and what is wanted is :-

c The judicious blending of the qualities of the thorouhgbred stallion with those of the well-formed young draught-mare possessing size, frame, constitution, flat legs, and high courage.

d From these half-bred mares so obtained, cross-breeding can be resorted to by the selection of the thoroughbred or hackney, and thus a stock of riding and driving horses, available for general use, will be secured, possessing improved size, strength, and constitution. 


\section{$(31)$ \\ DISCUSSION.}

Lord Carrington : Nothing on earth, Mr. Chairman, would have induced me to open my mouth before an assembly who have so much more practical knowledge than I have had it not been that I was requested by our Chairman to propose a vote of thanks to Mr. Walter Gilbey. I do so not as a member of the Club, and not, I am sorry to say, as a moderately successful farmer, but as one of his old friends, and one who has known his family long. In that capacity I have much pleasure in obeying your call to-day, sir. But if any person in England had told me on Saturday that my old friend, Mr. Tattersall, and I were going to make a motion which would be acceptable to a meeting of English gentlemen, and that would be received with enthusiasm, as I am sure this motion will be-if any person who had, like some of us here, passed last week in listening to the speeches in the House of Commons and in the House of Lords for and against the Vote of Censure on Her Majesty's Government-if anybody had told me that we were going to propose and second a vote which would be unanimously received at this present moment by any meeting of English gentlemen, I should have said that that man was clean out of his mind. But, gentlemen, we have listened to a practical subject, very practically dealt with by a man who knows what he is talking about. Perhaps I might be allowed to allude to the sale of Mr. Gilbey's cart-horses, which took place three weeks ago. That sale showed 


\section{$(32)$}

what can be done by a gentleman who goes into business with a knowledge of what he is about. The horses at that sale were all my friend's own breeding, and they were sold at what I think we can really call very fair value - that is, the price that a willing buyer will give a willing seller in the open market. Not only have we had the pleasure of listening to Mr. Gilbey, but we also have the advantage of having several very practical persons here this afternoon who are well acquainted with the breeding of horses. I think I ought to mention my friend, Mr. Anthony Hammond, who. I believe, was one of the original starters (I am speaking under correction) of the idea of the Hackney Society. We have also Mr. Frederick Street here, and his Grace the Duke of Westminster, who has given an example of what can be done by breeding, as he has bred a Derby winner himself. We have also my brother-in-law, Lord Hastings, who is one of the youngest breeders on the Turf, as well as one of the youngest members of the Jockey Club, and though he has only been breeding three years, he has the first favourite for the Derby, and I am sure every gentleman in the room wishes him success. Having so many celebrated breeders present, the discussion will, I feel sure, be of great interest. I should like to ask the gentlemen present whether they quite agree with what has been stated in this paper about selecting thoroughbred stallions. It is stated that thoroughbred stallions have not at this time the old attributes of strength and stamina. That is a question I should very much like to hear argued, and I am sure Mr. Tattersall, a very good judge, will be able to enlighten us on that point. There is also one point upon which hunting gentlemen will be able to enlighten us, I allude to the following quotation:- "I saw a farmer one day, when we were hunting with the late Ralph Lambton, take his mare from the plough, jump on her back, with winkers, bridle, and collar round her 
neck, and go for about five miles across country, taking every fence before him, and he was there when we killed our fox." When times were better, I had the pleasure of hunting a pack of hounds in a grass country, and all I can say is that if that farmer had taken his mare from the plough and ridden five miles after the Cottesmore hounds, he would not have been within three miles of the finish when we did kill the fox. It is not as a farmer or member of this club, but as a great personal friend of Mr. Gilbey, that I beg with great respect to propose a most cordial vote of thanks to him for his able, instructive, and exhaustive paper.

Mr. Edmund Tattersall: Mr. Chairman, my lords and gentlemen, it is a very great honour to me to be called upon to return thanks to Mr. Gilbey for the admirable paper he has read to us. Lord Carrington has been kind enough to refer to me in a very nice way, but I am sure of one thing, and that is that we all thank Mr. Gilbey for all he has said and done, because I think it will raise a very useful discussion. There can be no doubt on one point-that he has thrown his heart and soul into it. Everyone who knows $\mathrm{Mr}$. Gilbey and has seen his pictures and prints, knows he has studied this subject very deeply, and can show perhaps the best collection of prints and pictures in England with regard to horses. Of course there are many points that would raise discussion, but I do think Lord Carrington has touched on rather a weak point. I do not think the cart mare would have been so near the hounds as the paper states. I have no doubt we must go a long way back to get good mares, for I know from the best authority in England (Mr. Philips) that in the last twenty years the average number of mares sent out of this country, useful to breed from, has been not less than I,O00 a year. Just look what they would have produced in this time. They are the sort of mares we now want, and the foreigners have got them because they send over constantly; they 
have bought the mares here, and the only reason why we have none is, that they gave rather more money than breeders in this country could give. A long while ago I advocated a remedy for this in the presence of the noble Duke, and perhaps it is presumptuous on my part to speak again on it ; but I do not think it would have happened if we had what they have in every other country but England, a national stud. In Austria and Prussia they have 2,000 horses at least covering for the country at $7 s$. or Ios. a head; and there is not a horse travelling in those countries that has not a certificate of soundness from the Government. As far as the stallion goes that is the weak point here. Any wretched horse that cannot win a race is thought good enough to send round the country, and if he covers at a little less than a good horse standing close by he gets good mares. I have sold, to-day, a horse called "Cavaliero," out of "Cambuscan," a good enough horse. I asked the gentleman who sent the horse up the reason why he sold him. He said, "I had kept him two or three seasons, and last year they sent me six mares at $£^{2}$ IOs. a piece. That is my reason. I cannot afford to keep him for nothing." " Lord Coventry told me the same years ago, with respect to a very good horse he had. The difficulty is to get sound mares to sound horses. I believe there are many of them about the country, but unless it is made a business in the trade you cannot get them to send them to the proper mares. Of course, they do not like the trouble and bother of sending them far away, but if it was made a business to send through the country, that is how it might be managed. I took the liberty of asking a gentleman from Prussia what he thought was the annual cost of all their Government horses. After a little thought he told me he did not think it exceeded $£$ I00,000 a year-a mere fleabite. I know a great many good mares have gone, and I think it is very kind of Mr. Gilbey to tell us how possibly we may get them 
back again, for I am perfectly certain that every other horse you see in London is a foreign horse. The name of "Cavaliero" brings back the remembrance of my old friend, who is dead unfortunately. He said, "You are very foolish in your country to allow one of the finest strains to go out of it, and in not having proper stallions under Government control." I only hope that Mr. Gilbey's paper will have the effect of teaching us to breed good horses, for I think we are getting sadly deficient in horses for riding and driving purposes. If you ask any of the best dealers in London to get a pair of well-bred English carriage-horses, you will have to give an enormous sum for them, and they will have great difficulty in getting them at all. I most cordially agree with every word that Lord Carrington said with regard to the thanks due to Mr. Gilbey, and I am sure we all feel deeply grateful to him. I know it will please him most if we go and act on what he has said.

The Duke of Wrstminster, K.G.: Mr. Chairman and gentlemen-I share, I believe, a very common dislike among English gentlemen, that of making a speech, and I came here with the intention of listening rather than speaking, because really, in point of fact, I have very little practical experience in breeding halfbred stock, which, I suppose, is the main object and interest of our meeting here to-day. The chief difficulty, it appears to me on the face of it, is the exportation of so many of our best mares. Now, the evidence given before Lord Roseberry's House of Lords Committee some years ago-I think I shall be borne out in what I say by those gentlemen present who have read the Report, and who probably themselves, like Mr. Tattersall, gave evidence-showed that there was a general unanimity of feeling and opinion that the best mares of England, and especially Cleveland mares, had gone out of the country. The Cleveland mares were said to be almost non-existent, but I am glad to hear 


\section{$\left(3^{6}\right)$}

that there is a resuscitation of them, and that a Cleveland Society has been formed. The formation of that Society leads me to hope that there are one or two Cleveland mares left at all events, and that this breed may probably be re-established. It is, after all, a question of demand and supply, and the farmers will get the best price they can for their mares. I do not know how we are to prevent good mares going out of the country. There is one paragraph in the paper (which is an extremely able and interesting one, and shows Mr. Gilbey's thorough knowledge of the subject from early times) in which he says that the thoroughbred horse is more weedy than he used to be, but that, I think, hardly bears out the paragraph in which Admiral Rous is quoted as having said that whereas the average size of horses formerly was $13 \cdot 2$, the average since 1870 was $15^{\circ}$. I am inclined to think that you will find as many horses of size and substance now as ever. Of course, speed is the one essential to thoroughbreds, because after all racing is the only possible test of merit and you win by speed. The question of stamina is another thing. I quite agree that it is unfortunate that so many prizes are given to two-year-olds and that there are very few given to horses that remain on in training after three years old, so that it really hardly pays to keep them in training to an older age. All the greater prizes are given for two and three-year-olds, and it is very difficult to make four-year-olds pay, so that they are not kept, and we hardly know whether our horses have good substance and stamina. Anybody who knows anything about breeding will understand that it is absolutely necessary to breed from young, sound mares. Perhaps Mr. Gilbey would not mind adding the word "young" in the last paragraph but one (C) of his paper. I know it would carry out his intentions, and I think it would be better if that word was inserted in that paragraph. A lady friend of mine who had an old. mare that she had ridden for 


\section{$(37)$}

many years, asked me, when it was 23 years old, if it was not right to begin breeding from her. She quoted the opinion of some friends of hers--I think Sir Edward Sullivan was one-who told her that such and such a mare had produced a very good colt when it was 23 years old; but it is quite another thing to begin breeding at 23. I am afraid it is too often the case that when a mare has done good service and is worn out in her legs and constitution, it is supposed that it is the right thing to put her to any horse that may happen to be in the country. My own experience of half-bred stallions is this: I have a horse called Golden Cross ; he is by Brown Bread, and the dam New Oswestry, which has a stain in her pedigree; but he is in such demand that $I$ have no difficulty in getting sixty mares at $£ 5$ to outsiders, and $£_{3}$ to my tenants for him to cover. We have more applications than we can possibly take. Then I have a Norfolk pony covering at $£ 3$ to outsiders and $£ \mathrm{I}$ to my own tenants. I only mention these facts to prove that if you get a good animal you may obtain a price that will recoup you not only for the keep, but for your original outlay. There are good farmers and bad farmers, and the latter will always send to the nearest horse, however worthless he may be, which is very detrimental to the breeding of horses. But I am no expert, and I will conclude by saying that I cordially support the vote of thanks to Mr. Gilbey for his excellent paper.

Mr. Anshony Hamond (Westacre, Norfolk): As president of the Hackney Society, which is going to hold its first Show to morrow, I may perhaps be excused for offering one or two remarks upon this subject. I agree verycordially with a great many things said by Mr. Gilbey, and I think we owe him a great debt of gratitude for the way in which he has taken in hand the breeding of horses. But in regard to crossing, I must mention one thing, that almost every cart mare crossed with a thoroughbred horse breeds an animal which, in my 


\section{$(38)$}

humble experience, is not able to go out as many days in the week as a man who keeps only a few horses requires. The difficulty is in getting good back sinews. If you distress an under-bred horse one week, the odds are, that you won't get him out again for another three weeks, whereas, if he is a thoroughbred you will be able to ride him again within a few days. The great difficulty is how we are to get a weight-carrying horse of a strong strain and thoroughbred. With regard to the hackneys which are now going to be shown, I hope you will suspend your judgment as to what riding and driving horses there are in England until you have seen the Show to-morrow. I have in my hand a catalogue of exhibits which contains no less than 95 stallions of various sizes, some up to 16 hands in height, and between thirty and forty mares of the same breed. I may say one word about the title of the Society. We owe the starting of it to Mr. Euren, the editor of the "Norwich Mercury," a paper which has been published at Norwich ever since $\mathrm{I} ; 30$, or rather earlier, and which has kept records of all horses travelling, and all Horse Shows. He also is the well-known editor of the Norfolk and Suffolk, Red Polled Herd Book. For many years he has taken the greatest interest in what was called the Norfolk Trotter. He has searched every book that it has been possible to get on the subject, and has made his notes for about twelve years. He came to me some ten years ago to see if he could get a certain number of people to bring out and publish the pedigree and particulars of the horse known as the Norfolk Trotter. The Norfolk Trotter is an accepted term, but a great many of us know that besides the breed in Norfolk the same horse had been bred for many years in Yorkshire (especially in the Hull district) and other parts of England, and we thought that if we called it Norfolk Trotter we should be adopting too narrow a term. We, therefore, propose to enlarge it, and call the Society "'The Hackney Stud Book 
Society," established to improve the breed and promote the breeding of Hackneys, Roadsters, Cobs, and Ponies. Well, we could do nothing then. times were very bad, and the whole thing tumbled through until about two years ago, when Lord Hastings was president of the Norfolk Agricultural Show, and he alluded to the question at the annual meeting, held at Fakenham. A meeting was soon afterwards held at Norwich. His Royal Highness the Prince of Wales was good enough to say he would become patron, and the whole thing has now arrived at this stage, viz., that we have about 300 yearly members, besides some 100 gentlemen who put down ten guineas to start the society. The first Show is going to be held to-morrow, and I hope that all gentlemen present will see it and will join the Society. At a meeting held at Tattersall's Rooms some two months ago a suggestion came from a gentleman present as to whether a Show of a certain number of thoroughbred horses could not be held at the same time. Our answer was yes, if those horses were sires of half-bred foals. After some consultation, an influential committee was formed, and it was arranged that thoroughbred sires should be shown on the understanding that they undertook to cover so many mares at 50s. each. There are no less than 34 of these horses. The first one is a horse by Hermit ; others by such sires as Jolly Tar, by Prince Charlie, Dutch Skater, Sterling, Wenlock, Lecturer, The Cathedral, and so on. I think these names are quite good enough to show that there are certain horses going to be shown which will be within the reach of any farmer's use and will prove thoroughly good sires, and that our Show will demonstrate that we still have in England good stock, both thoroughbred and hackney.

The Duke of Westminster: There is one point which I omitted to mention in reference to an observation of Mr. Tattersall's with regard to the State providing stallions. It will be in the recollection of 


\section{$(40)$}

gentlemen present that Lord Rosebery's Committee in their report decided against that proposal as interfering too much with private enterprise. I have been a great deal exercised all through the year in the matter of the Queen's Plates, and my own feeling is very much in favour of giving prizes for thoroughbred stallions at Agricultural Shows, and so on. But the amount is not very large-about $£ 3,500$-and I found the difficulty so great, and that we were also going against the principle of the original institution of the Queen's Plates, that I was obliged to give up that idea. My friend, Lord Enfield, in the House of Lords, gave notice of a motion for enquiry with regard to this question, but after he had obtained a great deal of information from foreign countries he came to the conclusion that we cannot move at all in the matter, because he says it is so entirely out of the question for anything of the sort to be undertaken in this country owing to the enormous expense attending it.

Colonel Kingscote: I do not know that I have any business to make any remarks to you, but this is a most important subject, and one that I have taken interest in for some time past. His Grace the Duke of Westminster has just said that he has been in favour of the Queen's Plates money being given in prizes to thoroughbred horses for getting half-bred stock. That has been my opinion for a very long time. I felt that it was useless for the Government to start studs like they do in foreign countries, because anything undertaken by the Government in this country becomes of colossal size, is very hard to manage, and costs a great deal of money. Much more is done by private enterprise in this country than in other countries. There is no doubt the great thing we do want is to encourage the breeding of good half-bred horses for riding and driving. What won't do for riding very often will do for driving. There are two considerations with regard to this. We all know now-a-days that the farmer wishes to get the quickest 


\section{$(41)$}

return he possibly can for his money, and he does it much more quickly by breeding cart horses than he would by breeding half-bred horses. He does not get rid of the half-bred horses so quickly; they require more looking after, and are more liable to accident ; still, I do hope that there are in many parts of the country tenant-farmers and others who will continue to breed half-bred horses, and to them, I think, we may give a helping hand. By encouraging those who keep stallions, in giving them prizes the amount of which will assist them in the purchase of those horses we shall enable a better horse to be brought to the farmers' doors. The difficulty in this may be that a person who buys any sort of a thoroughbred stallion is not particular as to his hereditary soundness. I cannot help thinking, taking even the modest sum of $£ 3,000$ a year from Queen's Plates money, that in the month of September the country might be divided into different districts in the same way that the Royal Agricultural Society divides it, and in the principal towns in those districts prizes might be given for stallions that had been covering, at a small fee, mares belonging to tenantfarmers in that district. They might assemble in those towns. You would find very good judges, who would judge them, probably for nothing at all, or, at all events, only for their travelling expenses, and one good result would be that you would have these horses examined, and whether they won a prize or not, they should have a medal if they passed sound, that is, not having any hereditary disease. As soon as you had started these competitions, and I do hope that this Show that we are going to see to-morrow is only the beginning of them, I think you might in a year or two supplement it by a Show of brood mares and foals, those foals to be got, if not by one of the prize horses, at all events by a horse having a medal for soundness, That would do more to help the breeding of half-bred horses than anything else, putting aside the difficulty of having Government 
stallions or a Government stud. It is not only a question of profit to those who breed themselves, but to the public at large. We all know that the Government at this present time has the greatest difficulty in remounting their cavalry and artillery. I know a colonel of a regiment lately come from India, who tells me that he had the greatest difficulty to get horses even of very inferior size to what he had when he went out to India. This is a public question, and if the Government cannot take it up, I only hope that there is enterprise enough among individuals in this country to start this scheme, as I hope we shall do by the Show to-morrow, and to go on in the lines that I have very imperfectly indicated. I should like to add my tribute of thanks to those which have been given to Mr. Gilbey for his very able and most interesting paper.

Mr. J. K. Fowler (Lee Manor, Great Missenden, Bucks): I have been waiting for a tenant farmer to get up to say something on this great question. Only a few years ago I read a paper on breeding "Facts and Principles," and I endeavoured to lay down the dictum that we should look to the male animals for external appearance and locomotive power, and to the female animal for internal organisation. I think that has been tried, and has been found to be correct as a general rule. I am old enough to recollect when the oldfashioned post-horse and coach-horse was seen plodding along the main roads of England, and I remember old Bob Newman, of Regent Street, defining the best riding post-shay horse as being a good weight-carrying hunter. I perfectly remember the class of horses that could go twelve miles an hour with a gentleman's carriage behind them and that is a sort we cannot get at the present day. If the class of horse that has now been suggested by Mr. Gilbey could be produced and carried on I am afraid you would often get too soft an animal to go the pace and to carry the weight required as a hunter and a hack. Another question has 


\section{$(43)$}

been suggested about the Government taking this matter up. When I went to Austria some years since I learned that the Government sent round, and that if a farmer or any owner of land said he would undertake the management of a good entire horse they would send him one, and the whole district round could get the services of that horse for a very small sum, I do not think much more than Ios. of our money. I believe, also, that the money paid by the farmers went towards the keep of the horse. I think something of this sort could be done in this country, either that the Government themselves should assist, or that every master of hounds in England, where it was practicable, should be persuaded to keep a good horse for the use of the farmers in the hunt. I remember many years ago with the Queen's hounds they sent down a horse to Aylesbury called Carbonaro. Old Lord Lonsdale also sent a horse called Uncommon, brother to Jericho, a remarkably good animal. Sir Nathaniel Rothschild now kindly keeps a horse for the use of the farmers of the district. I believe that system might be carried on throughout the country with a very great deal of effect. I think such is the knowledge of masters of hounds that they know the class of horse that is required in their district, and would try and select that animal which they thought to be best to produce a hunter fit for themselves or other people to ride. I may say one other thing. As a farmer I have tried the breeding of horses, and I have always succeeded remarkably well with cart horses, and if one is bred with any defect, a farmer can keep him for his own purposes, and he makes a good useful slave to carry on the operations on his farm. But if he gets a defective horse, as a racehorse or a hunter, he can do nothing with him-it is a very difficult thing for him to know what to do. Such things will occur, and, as a matter of $£ \mathrm{~s}$. d., you will find farmers are very chary of trying to breed what is called a nag-horse. 
Mr. F. Sherborn (Bedfont, Hounslow) : We have had a very excellent paper, but although we have listened to several speakers, I have not heard anyone yet touch very particularly upon the important point of all-will it pay? that is what we want to know. If you can prove that it will pay to breed nag horses, I am sure tenant farmers will be very glad to do so. I have done a little in that direction myself. Three years ago I had a magnificent horse 22 years old, still perfectly sound and unblemished, handsome, perfect in temper and colour, and vigorous as any four-year-old could be. I have had that horse three years, and though I have let him at three guineas for half-bred mares, I have not had more than five mares in a year. This shows that there is very great difficulty in bringing this subject to the front. I hope that something will be the outcome of the Show to be held this week. I should be very glad if I can give you further information on the subject.

Mr. JACOB W ILSON (Chillingham, Northumberland): I can assure you I came here with the sole purpose of being a listener and a learner, and, like many others, I have not come in vain. The subject is one which, undoubtedly, in the public mind, is ripe for action, and I feel confident that the future (which I believe will be a great future) will. take its commencement from the excellent paper read by Mr. Gilbey this evening. It has been said very properly that the whole question is one of supply and demand, but, unfortunately, it is the competition between English private enterprise and means and the money of foreign Governments. And the only way, therefore, to fight this battle is to fight it upon the principle of supply and demand, and with the weapons employed by the foreigners. You must outbid the foreigner if you want to keep your good horses and mares at home. It is impossible for one moment to think that you can impose any tax or fiscal embargo against the exportation of mares from this country. Foreigners have a double motive in buying our 
mares. They require them first for their cavalry or artillery, and afterwards for breeding purposes, so that it is practically impossible in the present condition of agriculture for the tenant farmer of England to compete with the foreign buyer, or to refuse the temptation of a high price for his mares. Mr. Sherborn has touched upon a very important subject also, and it is this - that it must not be thought for a moment that the farmers of England as a body can attempt to breed hunters or cart horses everywhere. You must have all the necessary conditions present for so doing. There is a great deal of rough grass land (I speak more particularly from a knowledge of the North of England) where horse-breeding was formerly carried on with very great success, but that seemed to give way under land improvement and land drainage, whilst the tempting prices of beef and mutton have subsequently caused the rearing of cattle and sheep to be substituted for horses. But whether we can by any means (yet to be devised) tempt the British farmer to return to it, I am not at all prepared to say. Of course the difficulty is, as the Duke of Westminster has said, in keeping at home the raw material in the shape of our mares. I regard with very great satisfaction the movement started with regard to this question. It has been encouraged very much by the success which has attended the breeding of cart horses of various kinds, both Shire and Clydesdale. I have been practically interested for the last ten or twelve years in the importation of good draught stallions from Scotland into the north of England, and even ten or twelve years ago saw the importance of it, and gave 400 guineas for the hire of a Clydesdale stallion for one season, and with the very best results. It is very encouraging to observe that the younger stock at the recent Shire Horse Shows is a great improvement upon the older classes. The time has arrived when the attention of the public should be devoted to the improvement of other breeds of 


\section{$(46)$}

horses. As one who is interested in the stock of England generally, I, in my humble way, with Colonel Kingscote and other friends, have been trying to move in this direction, and a Committee of the Royal Agricultural Society, which has been appointed, is about to sit to consider the whole question of breeding Hunters. If, therefore, any gentleman present has any practical suggestions to offer, I hope he will not hesitate to hand them in to us. I cordially join with those who have spoken in my meed of thanks to Mr. Gilbey for the very admirable paper to which we have listened this evening.

Major Dsshwood (Kirtlington, Oxford) : Mr. Chairman, my lords and gentlemen, as the last speaker has referred to the duty of all here present who haveany practical experience, trying to give the benefit of it to others, I will try to do so. I have bred horses off and on for a good thirty years; I have bred thoroughbreds ; I keep a shire-bred stallion, and I have bred several half-breds. The best that I have ever bred-and I have her now-was got out of a light cart mare by a $\Lambda$ orfolk trotter, and that is why I wish heartily to support the Show that we are to have to-morrow. In our county-Oxfordshire-the Earl of Abingdon, for many years past, has kept trotting stallions which, I understand, have got very useful stock. I do not altogether agree with putting a thoroughbred sire upon a cart mare, the natures are too opposite, therefore, these trotters, if with size and substance, will become a valuable breed to put on the light cart mares. As regards tenant farmers who breed in my district, I know some who have been very successful. They have had well-bred mares which they put to light cart stallions. One of these was a Suffolk stallion and he got very fair stock; but, as a rule, the joints from the Suffolk cross were not good. I know a farmer who bred very useful animals, and I asked him to tell me something of his experience. He showed me an old mare which 
I understood belonged to the Rothschilds, and I believe was thoroughbred. He got his useful animals by putting her to a cart stallion, a short-legged horse, 16 hands high, with a touch of "blood" in him. I saw some of his stock, very nice animals they were. The farmer told me that he has not the slightest difficulty in parting with them. What I want particularly to support is the breed of these trotting stallions now called "hackneys," I think they will be very valuable to put on the light cart mares. The great authority on horsebreeding in Oxfordshire told me that his impression was that it was better to put a light cart stallion upon a well-bred mare than a thoroughbred stallion upon a light cart mare. While entirely agreeing with this-I am sure there is nothing like " blood," but my opinion is that without size and bone blood is of little value; get size and bone, and some blood, you have then a mare fit to put to a shortlegged, stout, thoroughbred horse. There is one other remark I will make. I think there are several gentlemen here who do not belong to this club, and I may tell them that it was from this club that the Shire Horse Society was started, and it is also through this club that we have had the opportunity of listening to Mr. Gilbey's very important and most valuable paper. Therefore, after what Mr. Hamond has remarked, I would add that if there are any gentlemen here who wish to join this, "The Farmers' Club" I shall be only too glad to take their nominations.

Mr. T. B. Woodward (Hardwicke Bank, Tewkesbury): I have only risen to make two remarks. Mr. Gilbey says on the first page of his paper: "It is an admitted fact that the true-bred English hunter, hack, carriage, and draught horse cannot be equalled in any other country." May I ask him the simple and straightforward question. Is it owing to climatic considerations that England is superior to any other country, or is it due to any other cause. If not, I suppose the explana- 


\section{$(48)$}

tion would mainly be that given by other gentlemen who state that our best mares have been taken out of the country by the higher prices given for them. The second observation $\mathrm{I}$ wish to make is with reference to the formation of a stud-book for horses. I have had no experience myself in breeding thoroughbred horses, but some years ago, in connection with my late father, I had a good deal to do with the breeding of cart-horses and shorthorns. The remark I am about to make may be considered heresy by Mr. Thornton, but I think that in dealing with horses the judgment of sensible men would be that really no horse ought to be eligible for entry unless he has won a prize somewhere or other; because if you allow a horse to be entered on the strength of his blood only you may have an unlimited number of bad ones in your book. As to shorthorns, we know that all animals which have three generations of pure blood in them may be entered 0 : the books, and several practical men who have looket at this subject from a scientific point of view have comet to the conclusion that it would be better if we were stricter as regards the rules as to eligibility for entry.' The first consideration is that the good points shall be maintained and developed in a horse, and therefore the observation I have made will exactly tally with the suggestion of Colonel Kingscote, namely, that if entire horses are spread all over the country, it will be to the farmers' interest to use either a stud-book horse or a medal horse-that is to say, one which has won a prize at a country Show or been highly commended, and in this way the inferior horses now travelling the country would be set aside.

Captain FIFE : No doubt it is greatly with the view of what the last speaker has said that the Show and prizes for thoroughbred stallions have been started. We hope it may develop what the last speaker has said, namely, that the bad horses which are not good enough to win prizes will be driven out of the country for the 
want of patronage, and that the good ones will be brought to light by being awarded prizes, and thus these owners who have good horses will find that they have plenty of custom for them. His grace the Duke of Westminster said that he always found that the list for his stallions was very well filled up, and I have no doubt that other good horses would get the same patronage. With regard to the remarks that were made as to the breeding of nag horses paying, I believe that if farmers would breed from younger mares-if they would go and buy a three-year-old filly from an Irish drove, that three-year-old would keep growing into money. The purchaser might keep her for two years, and then sell her as a five-year-old at a profit, and at the same time, instead of lying idle, the mare might breed a foal, and the owner would not have the expense of the keep of the brood mare to add to the $r$ ist of the foal, the brood mare having paid for her eep by being sold at a profit. That is one way of raking breeding pay. The other way is by working the dam and thus making it earn its keep-working it on the land, or using it for general harness purposes. Breeding from mares kept solely for breeding purposes cannot have as good a chance of paying as by following the above alternatives. There is no doubt that something should be done to improve our supply of mares in the country. A mare as a brood mare has no special value as she ought to have, and I think if prizes were given for the best brood mares at this Stallion Show another year, it would be a move in the right direction, and I also think that there should be a class for mares that have never been put to the stud, but which are suitable for breeding hunters. I think that many people who have a mare, perhaps without any intention of breeding from her, might say I will show her in this class. They might show her, and perhaps they might win a prize, and that very likely would be an inducement to the owner to breed 


\section{$(50)$}

from that mare, whereas otherwise it might not have entered his head to do so. I came this afternoon quite unprepared to address you, and I beg you to excuse all my shortcomings. I wrote a letter in the "Field" last week, which expresses my views more clearly than I have been able to express them to you now. With regard to a stud book, that is an idea to which there are a great many objections. I think that more people object to it than approve of it, and I proposed, as you may see in my letter to the "Field," an alternative which might improve the breed of brood mares without establishing a stud book. It was that all mares who win prizes or are commended at the Shows should be entered in a book, and that this book should not be called a stud book, but " Hunters' Prize Book." Prize stallions would be entered in the same way, and of course, if the produce of the prize mare and prize stallion again got entered in this book that animal would be very valuable as a brood mare. I think this would add a great deal to the value of the brood mares in this country, and perhaps the owners of good animals would be very likely to think twice before parting with them. By this means they are more likely to be kept in the country instead of going out of it.

The Chairman then put the question, which was carried unanimously.

Mr. Gilbey, in reply, said-Mr. Chairman, my Lord Duke, my Lords, and Gentlemen, I fully appreciate the vote of thanks which you have passed, and in replying to the various remarks made during the discussion, having taken up so much of your time, I shall endeavour to be as brief as possible. First, as to the thoroughbred horse, I had no intention of disparaging this animal, because, for turf purposes, I believe he has been bred with more speed and consequently is more valuable, for the greatly increased number of races, and high value of the stakes for which he now competes. I will, however, refer 


\section{$\left(5^{\mathrm{I}}\right)$}

you to the engravings and paintings of "Marske," "Eclipse," "Mambrino," and "Shark," and I think you will then admit that thoroughbreds. at the present time, although they have increased in stature four inches in the past hundred years, have not, at any rate, the attributes of strength they had in the last century. To realize this fully, it is perhaps necessary that you should have the same faith in Stubbs that I have. My belief is, that he could only portray on canvas the animals as he saw them, and we have in the pictures I have here with me the thoroughbred as he existed in his time.

As to the remarks of my friend, Mr. Edmund Tattersall, I should state that I am not a believer in Government assistance for the objects we have in view. Private enterprise has carried us thus far. If we wait for State aid, the loss to the country will be still yearly going on ; and "while the grass is growing the steed is starving."

Again, it has been stated that in certain parts of England, where Thoroughbred stallions have been located, they have not been patronized by farmers and others. This does not coincide with my experience, neither with the experience quoted by His Grace the Duke of Westminster. My stallions have been for years well patronized, the Service fees regularly paid, and yet they do not travel, but serve mares at my own Paddocks only.

On the all-important point of breeding, I should scarcely have ventured to make the propositions I have done here to-day if I could not have supported them by quotations from well-informed writers, giving many satisfactory results of mating Thoroughbred Stallions with Draught mares. I am sorry circumstances do not allow of my reading many letters on this subject, received from practical breeders, expressing as they do approval of my ideas in regard to the mating of Thoroughbred Stallions with Draught 


\section{$\left(5^{2}\right)$}

Mares. I regret also that Mr. G. M. Sexton has been prevented attending this meeting; it was his intentiont to be here; his experience is interesting. $\mathrm{He}$ has been successful in breeding, three years in succession, from a Suffolk mare, and each year by different thoroughbred stallions. The produce-three in number-he has sold when young, realizing nearly $\mathcal{E}^{600}$, and they have turned out very valuable weightcarrying hunters. I could enumerate many other successful instances which have come under my notice, but will only mention one more. A nephew of mine put a thoroughbred mare to a draught stallion. The produce was a filly which when two years old he put to "Reality," Mr. Flanders' famous Hackney stallion, and as a result he has a yearling which is sizeable, with good action, and promises to turn out valuable.

I may add also that I am a believer in the use of the Hackney stallion for cross-breeding - provided suitable mares are mated with him-as he will assuredly impart to his progeny that high trotting action not to be obtained in such perfection in any other way.

As to the suggestion offered by $\mathrm{His}$ Grace the Duke of Westminster to add the word "young" in the last paragraph (C). I willingly accept the proposition, as my meaning is fully in accordance therewith.

In reply to Mr. Woodward, I have already said it is an admitted fact that the true-bred English hunter, hack, carriage, and draught horse cannot be equalled in any other part of the world ; therefore, with the old stock now in the country, with proper food, and the love which every Englishman has for the noble animal, we may still hold our own. Depend upon it there is more in these things than in either climate or soil. 



